\title{
Private international law issues of intellectual property: The online dimension in Belarus
}

\section{E. Leanovich}

Belarusian State University, 4, Nezavisimosti pr., Minsk, 220030, Republic of Belarus

For citation: Leanovich, Elena. 2020. "Private international law issues of intellectual property: The online dimension in Belarus". Vestnik of Saint Petersburg University. Law 2: 431-446. https://doi.org/10.21638/spbu14.2020.212

The main peculiarity of intellectual property rights in the domain of private international law rights is rooted in the territorial character of these rights. Territoriality complicates the process of applying conflict of laws rules, recognition of foreign courts' judgements and arbitral awards and operation of other mechanisms of private international law in respect of intellectual property. Intellectual property relations on the Internet are immanently international in their nature. They usually include the so-called "foreign element," which launches the mechanisms of private international law. At the same time, the specifics of the online environment and the complexity of solving the conflict of laws of intellectual property due to its territoriality outline a frame of legal research. The main challenges are connected with the possibility, expediency and specificity of the application of mechanisms of private international law to intellectual property relations on the Internet. The principle of territoriality of intellectual property is strictly understood in the legal system of the Republic of Belarus. Application of foreign laws on intellectual property and recognition of intellectual property rights based on them demand profound legal justification, and in the majority of cases are hardly possible. The article illustrates reasons to revise this approach in relation to intellectual property in general and intellectual property on the Internet in particular. The author suggests methods for a gradual transition to the flexible understanding of the territoriality of intellectual property and incorporation into the Belarusian legislation of new material and conflict of laws rules.

Keywords: intellectual property rights, private international law, conflict of laws, territoriality of intellectual property, territorial character of intellectual property rights, online intellectual property relations, digital rights, ubiquitous infringements, ubiquity, Internet service providers.

\section{Introduction}

Intellectual property is crucial for the functioning of the Internet. Actually, this global system of connected networks is based on intellectual property objects. Due to information technologies (IT), especially digitalization, it is possible to use all the objects of intellectual property in the Internet environment as far as it concerns the works that comprise the content of Internet resources and computer programmes that present the whole technical structure and "modus operandi" of the Internet. It is almost impossible to act on the Internet without dealing with intellectual property issues. Thus, the online dimension of intellectual property rights protection and enforcement appears quite often. However,

(C) Санкт-Петербургский государственный университет, 2020 
despite the global nature of the Internet, legal analysis of these issues is highly dependent on national jurisdiction.

The Internet challenges traditional private international law methods of determining applicable law and proper jurisdiction. As a matter of fact, the Internet is free from national boundaries and is characterised as a virtual space. The basic localisation factor "loci", meaning in terms of private international law the place in a particular country, does not work well enough. Nevertheless, it is possible to identify geographical Internet-segments, geographical domain names and other signs of interconnection between Internet relations and national jurisdictions. The localisation factor "loci" can be replaced by others, for example, the nationality of a right holder or infringer, the origin of protection, and the place of registration. When we pose two main questions in regards to private international law: 1) where do we take legal action; 2) which law is applicable, we mean the real world of national courts and legislation, not its virtual substitute. The issue is does this virtual substitute exist or can it be organized? There are some schemes for resolving private international law problems on the Internet without referring to national legal systems. As of now, the Internet has already convincingly demonstrated its self-regulation ability. To a large extent, this ability concerns technical aspects, for example the universal unity of the Internet. From the legal point of view, methods of self-regulation can be seen in the practice of disputes on infringements of intellectual property rights in domain names. The World Intellectual Property Organisation (WIPO) Arbitration and Mediation Center provides flexible processes and techniques to resolve the Internet domain name disputes without the need for litigation in state courts. Thus, the first question of private international law can be omitted. The second question, not necessarily, but it can be redundant as well. The "WIPO Overview of WIPO Panel Views on Selected Uniform Domain Name Dispute Resolution Policy (UDRP) Questions ('WIPO Jurisprudential Overview 3.0')" says: “... a panel shall decide a complaint on the basis of... any rules and principles of law that it deems applicable" ("Overview of WIPO Panel Views on Selected UDRP Questions. WIPO Jurisprudential Overview 3.0”. 2017. 3 edn. para. 4.15. Accessed April 2, 2018. www.wipo. int/amc/en/domains/search/overview3.0). It appears that the UDRP system is so broadly accepted that it can operate as a global representation of general trademark law principles and it is not necessary to apply particular national laws.

The main purpose of this article is to outline new tendencies in private international law, including legal grounds and possible obstacles for the development of self-regulation mechanisms of the Internet in respect to intellectual property relations. These problems have significant importance for Belarus. There are prerequisites for the intense development of the Internet's intellectual property relations, but there is no relevant practice. On the one hand, the absence of disputes can be explained by the "bona fide" behaviour. On the other hand, the existence in Belarus of a significant number of Information and communications technology (ICT) companies provides the grounds to assume that the practice of infringements is latent and rightholders just do not know how to defend their rights, especially on the Internet. The Belarusian legislation does not provide special regulation of Internet relations and the Internet self-regulation practices have not been developed in the national segment of the Internet, in particular for the domain .by. The UDRP mechanisms have not been established for it. First, we investigate the issue in the context of the existing private international law mechanisms. Second, we set ourselves the task of finding the necessary changes and improvements to these mechanisms. 
There are many scenarios for the development of Internet relations that can result in the necessity to apply the norms and mechanisms of private international law. Presently, they are being carefully studied in the private international law doctrine. In particular, Andrew F. Christie revealed that in most cases an infringement is at stake ant it involves "a local plaintiff suing a foreign defendant for a foreign action that causes local damage to a local IPR (being either a trademark or a copyright)" (Christie 2017, 164). It is possible to discuss the prevailing foreign elements in a matter. The situations when a foreign claimant wants to defend intellectual property rights in the case of foreign infringement in the jurisdiction of a defendant are vital as well. The assets from which a satisfaction ruling can be obtained are usually located in this country. Nevertheless, we agree that the main sphere of interests concerns an infringement. The most common association of this type of relations (infringement) with the problem of intellectual property rights on the Internet is highlighted in the materials of the International Chamber of Commerce (The ICC Intellectual Property Roadmap - Current and emerging issues for business and policymakers. 2017. Accessed April 12, 2018. https://iccwbo.org/publication/icc-intellectual-propertyroadmap-current-emerging-issues-business-policymakers). Sharing this point of view, we also turn to the relations of intellectual property rights on infringements with different kinds of foreign elements.

\section{Basic research}

2.1. Territoriality of intellectual property opposes ubiquitous intellectual property relations. The notion of "ubiquitous" is not clear enough from the legal point of view, but tries to express an immanent connection of the infringement with several jurisdictions. It became widely used due to "Intellectual property: Principles governing jurisdiction, choice of law, and judgments in transnational disputes" (ALI Principles) of the American Law Institute (Intellectual property: Principles governing jurisdiction, choice of law, and judgments in transnational disputes. St. Paul, MN: American Law Institute, 2008) and "Principles on Conflict of Laws in Intellectual Property" (CLIP Principles) of the European Max Planck Group (European Max Planck Group on Conflict of Laws in Intellectual Property. Conflict of laws in intellectual property: The CLIP principles and commentary. Oxford: Oxford University Press, 2013). Both documents were prepared by leading specialists in intellectual property and private international law. They contain model rules that can be used on private international law issues in disputes concerning intellectual property relations with foreign elements.

In particular, CLIP Principles contain rules regulating international jurisdiction, applicable law, recognition and enforcement of foreign rulings in the field of intellectual property. This document consists of norms for clarification and adaptation of private international law to the specifics of the Internet environment. CLIP Principles Article 2:203:(2) assigns a special characteristic of ubiquity to the Internet. It states "ubiquitous media such as the Internet" and acknowledges that infringements may occur anywhere. However, the question is whether the ubiquitous infringement is the infringement for all targeted or accessed countries? And, is it important in the country where protection is demanded? Thomas Petz emphasizes that answers lie not in the area of conflict of laws and other mechanisms of private international law, but in the material law of the abovementioned country ("loci protectionis") (Petz 2012). We share this point of view. The 
rationale for this approach has roots in the concept of territorial character of intellectual property rights. If the legal system of a country proceeds from a strict understanding of the principle of territoriality of intellectual property rights (as in the case of Belarus), then the application of foreign laws in order to recognize the fact of a violation, to count the amount of damages, etc., is hardly possible.

The territorial character of intellectual property rights means that protection of these rights is granted for the territory of the country where it is requested and is regulated by the law of that country. National intellectual property laws do not have an extraterritorial effect, i. e. they do not apply on the territory of other states and intellectual property rights based on foreign legislation are not recognized abroad (Bliznets 2018, 15). Intellectual property rights are characterized by a territorial principle that is universally recognized throughout the world (Shugurova 2010, 76). The territoriality is presumed and may be overturned on the basis of special provisions of national and international law. Exemptions of this kind are rare in Belarus. They are limited to some intellectual property rights and objects, and are allowed due to the precise provisions of legal acts. For example, exclusions from the principle of territoriality are set in the following sources of legal regulation applicable for Belarus, for example the Paris Convention for the Protection of Industrial Property (Paris Convention) (Article 4A(2)); Madrid Agreement Concerning the International Registration of Marks (Madrid Agreement) (Articles 4 and Article 6(2)(3)); Berne Convention for the Protection of Literary and Artistic Work (Berne Convention) (Articles 5(2) and 7(8)); Law of the Republic of Belarus on Copyright and Related Rights (Copyright Law of Belarus) (Article 5.2); Law of the Republic of Belarus on Geographical Indications (Article 3.3) (WipoLex "Belarus (77 texts)". Accessed 14 April, 2018. http://www. wipo.int/wipolex/en/profile.jsp?code=BY).

The rules of jurisdiction of the Code of Civil Procedure of the Republic of Belarus of January 11, 1999 no. 238-3 (Accessed April 15, 2018. http://etalonline.by/?type=text\&re gnum=HK9900238\#load_text_none_1_) do not exclude the possibility of filing a lawsuit in Belarus despite the fact that an infringement of intellectual property rights took place abroad. It also concerns cases where the place of an infringement is unknown or cannot be associated with one country. The basic rule of international jurisdiction is the place of residence, stay or location of a defendant (fixed in Article 545 of the Code of Civil Procedure). Therefore, disputes arising from the intellectual property rights infringements with a variety of foreign elements: foreign nationality of a rightholder; infringement of rights abroad, etc., can appear in Belarusian judicial practice.

Solving the problem of territoriality on the basis of a strict approach means that in the case of foreign infringement, recognition of rights for compensation is dependent upon protection in the Republic of Belarus. Protection and enforcement cannot be attributed to different jurisdictions. It is fair if the protection of intellectual property rights is a key issue. Conversely, it is unfair if the principle of territoriality does not allow taking into account the relations that have legally arisen abroad in accordance with the legislation of a foreign state, especially when the key issue does not concern the infringement of intellectual property rights.

In one of the cases considered by the Belarusian Supreme Court, an identical sign was protected as a trademark in different jurisdictions and belonged to rightholders of a different nationality and the foreigner could not use this sign for TV-broadcasting, that was accessible in the Belarusian territory from the place of protection (Belarusian 
Supreme Court Bars Popular TV Channel from Using Name. 2014. StatesNews Service. Retrieved November 15, 2018. Accessed April 15, 2018. http://www.highbeam.com/ doc/1G1-381394524.html?refid=easy_hf). The foreigner could not demand recognition for intellectual property rights and the Belarusian court did not have legal grounds to recognize trademark rights claimed on the basis of the registration valid for Poland and other EU Member States. However, this case can be quite indicative from the point of view of the possibility and expediency of distinguishing between the issues of protection and enforcement, since the protection granted in one state is a legitimate basis for carrying out commercial or professional activities of international character, i. e. affecting or reaching the territories of other states. Hence, there is a difference between the terms of trademark infringement and activity as such. As the activity is ubiquitous, it will somehow manifest itself in the territory of different states.

CLIP Principles Article 3:603: provides that in disputes on ubiquitous infringements the question of applicable law can be solved on the basis of the rule of the close connection. In this case, courts and parties can find many ways to localize a disputed relation in a particular legal system. In determining which country has the close connection with an infringement, CLIP suggests taking into account all relevant factors, in particular: the infringer's habitual residence; the infringer's principal place of business; the place where substantial activities in furtherance of the infringement in its entirety have been carried out; the place where the harm caused by the infringement is substantial in relation to the infringement in its entirety.

There could be other factors which can be considered in the process of localization as well. CLIP Principles suggest a logical solution, but it lacks setting a goal. The conflict of laws of this document is devoted to finding the best linkage with a country. The multiplicity of connecting factors is fully recognized by the modern doctrine (Baranovskiy 2005). However, it is more important to establish connections of disputed relations with legal systems, not places.

The strict territorial approach that has become widespread in the legislation and practice of Belarus does not allow such a method of localization. Article 1132 of the Civil Code of the Republic of Belarus states that the law of the country where protection is sought is applied (Belarus: Civil Code [Belarus], no. 218-Z, 7 December 1998. Amended as of December 28, 2009. Accessed April 15, 2018. http://www.refworld.org/docid/4c21c0d62. $\mathrm{html}$ ). It is formulated as "lex loci protectionis". But, as a matter of fact, it orders Belarusian courts to apply the Belarusian law and functions as "lex fori". The word "where" cannot be interpreted by Belarusian courts otherwise. Moreover, it is quite difficult to imagine the situation of the application of this article abroad by another body, for example arbitral tribunals. Exclusive jurisdiction in disputes on the protection and enforcement of intellectual property is not fixed, but it is determined by material norms of the Belarusian intellectual property legislation. The arbitrability of disputes on intellectual property relations with a foreign element is unclear and hardly possible on questions pertaining to the protection of intellectual property objects, especially industrial property objects, which demand formalities (patenting, registration). The main implication of the strict territorial approach in the domain of private international law is that relations, which are legal according to foreign law, cannot have consequences abroad and rights based on them cannot be exercised. This situation forms the main challenge of modern private international law in the era of the global information society. 
The abovementioned case did not touch upon the problem of ubiquitous infringements. It showed that, although the norms of private international law in Belarus recognize the existence of intellectual property relations with a foreign element, in fact these norms do not fulfil their regulative functions, since in their absence results will be the same. Considering the need for changes in Belarusian private international law, it is necessary to clarify goals and expected results. CLIP Principles, ALI principles and other examples of the new private international law rules for intellectual property provide many models that can be followed. However, in our opinion, the improvement of Belarusian private international law should proceed primarily from the interests of the Republic of Belarus.

First of all, it is necessary to determine the goals of the flexible understanding of the principle of territoriality of intellectual property rights. It would then be possible to identify the appropriate means of implementing the modernized understanding. The specifics of intellectual property relations on the Internet, in particular ubiquitous infringements, can serve as effective indicators. The territoriality of intellectual property helps to maintain national interests of economic development. It can ensure free access to scientific and technical achievements that are of great importance for countries demanding expedited innovative development. The supportive function of the principle of territoriality is more apparent for inventions and other intellectual property objects, which comprise technological knowledge and skills.

Lydia Lundstedt begins her detailed and comprehensive study of the various approaches to the territoriality of intellectual property in the EU Member States and the United States by indicating that "A basic premise of the territoriality principle of IP law is that each state determines whether and the extent to which IP rights exist and are protected within its own territorial borders" (Lundstedt 2016, 1). We can also add that such a determination is crucial for the sovereignty of each state. Henning Grosse Ruse-Khan rightly pointed out that intellectual property law is essentially based on state measures that regulate private law relations among rightholders, users, competitors and the general public and form part of the eminent domain of the state to regulate (Ruse-Khan 2017). Taking into account the needs of economic, industrial and innovative development of the Republic of Belarus, we state that abandonment of the principle of territoriality is premature, but transition to the flexible understanding of territoriality is desirable.

It is necessary to deal with the problem of the territoriality of intellectual property, taking into account the specifics of relations having foreign elements. Since the time of Friedrich Carl von Savigny it has been generally recognized that these relations are initially connected with several legal systems and need to be distinguished from national relations. It is unfair to localize them in one of the legal systems in accordance with one criterion and then consider them as national relations. Foreign elements designate the specific legal status of relations. Friedrich Carl von Savigny advocated focusing on intentions of parties, their demand to create obligations and obtain goals. The revolutionary breakthrough of his theory is mainly connected with a new way of localizing. Instead of a single factor, it provides a combination of factors indicating close connections of a relation with an applicable law. It is important to note that due to this method the connection is established not with a country, but with its laws. Under Savigny's approach, the main goal is to provide harmonized and neutral choice of law rules that benefit all stakeholders (states, litigants, judges, etc.) by producing decisional harmony in all courts considering the same choice of laws issue (Dubay 2012). 
Thus, the general rule of Article 1132 of the Civil Code of the Republic of Belarus is not sufficient. It must be supplemented by the conflict of laws rule of close connection in order not to deprive the parties from the opportunity to rely on the legitimacy of relations that originated abroad. The rule of close connection should obtain an auxiliary meaning and be applied on the demand of an interested party, subject to sufficient justifications provided by this party. Combined conflict of laws solution, by using the criterion of close connections as an additional mechanism of private international law, allows taking into account intellectual property relations legitimated abroad. It is inappropriate to support the concept of territoriality leading to the recognition of non-existence of these relations. It is necessary to begin a gradual transition to the flexible understanding of the territoriality of intellectual property and to supplement the Civil Code of the Republic of Belarus with new conflict of laws rules. They will not give rise to the recognition and enforcement of foreign intellectual property rights. This issue must be decided on the basis of special material norms of Belarusian legislation and international treaties. Moreover, grounds for the emergence of legal protection of intellectual property rights can be qualified as public order (Article 1099 of the Civil Code of the Republic of Belarus) or mandatory rules (Article 1100 of the Civil Code of the Republic of Belarus). The main goal of the proposed changes is to meet current challenges of the digital economy. In the globalized world of intense information and economic exchanges, transnational obligations should not be impaired by the fact that in one jurisdiction the person who is a party of the intellectual property relation can be deprived of rights (for example, to receive compensation or consideration) or otherwise gets negative and unfair consequences of the principle of territoriality (for example, trademark squatting). Furthermore, the analysis of ubiquitous infringements in the domain of private international law illustrates that the principle of territoriality can not only cause these negative consequences, but it simply impedes the application of private international law mechanisms because they are traditionally oriented at finding a precise territory while "...private actors, whether right-holders, users, competitors, or infringers, are largely unable to stop the effects of their activity at the borders" (Dinwoodie 2009, 772).

2.2. Ubiquity demands specific private international law mechanisms. The phenomenon of the Internet as a global system of connected networks based on technical unity (TCP/IP, HTML), without national borders, creates specific conditions for legal regulation and resolution of intellectual property relations. Such transnational relations have developed significantly and are of great importance in the modern economy. It is important to create the legal framework of a supportive effect to the online intellectual property relations. At least it means that the commercial turnover of intellectual property rights should not be jeopardized. As the majority of cases on the online intellectual property relations are connected with the illegal commercial use of works, phonograms, trademarks and other intellectual property objects, it is necessary to understand the relativeness and contiguity of the factors in assessing the illegality in ubiquitous infringements. Thus, the specific legal regulation of the online intellectual property relations should have the characteristics of adequacy. It implies not only taking into account the essence of the relationship and various models of its regulation in different jurisdictions, but also the ability of the Internet to provide the means for assessment, assignment and allocation of intellectual property rights online. 
Andrew F. Christie conducted a comprehensive study on quantitative and qualitative indicators of intellectual property infringement disputes (Christie 2015). The author illustrated special private international law considerations with respect to online aspects. The results obtained lead to the conclusion that courts take into account private international law rules and mechanisms, but they are not decisive, and disputes can be resolved without them. The choice of law was not considered in most cases. Andrew F. Christie noted that it was directly addressed in a third of cases $(29 \%)$. The reference to international law was made only in two cases and in one case it was not applied because the court declined to accept jurisdiction over the matter. The most popular issue of private international law (two-thirds - 66\% - of the evaluated cases) was the definition of jurisdiction. However, this question is generally attributed by the presence of a foreign element in the relation considered by the court. Finally, no local enforcement was sought for foreign judgments (96\%). The demand for recognition and enforcement was determined for only two cases and it was considered satisfactory. Nevertheless, the revealed lack of demand for this mechanism of private international law shows that in the cases of ubiquitous infringements, the injured party does not rely on the ability to defend intellectual property rights abroad. It can be assumed that either rightholders do not trust the traditional mechanisms of private international law allowing for the consideration of a dispute in their domestic jurisdiction, or online alternative dispute resolution procedures are used and the results of these procedures can be enforced without national judicial systems.

Andrew F. Christie based his study on the materials from the practice of developed countries (56 cases from 19 jurisdictions). These countries have large online markets with significant turnover. This situation determines the prerequisites for the intense development of Internet relations on the use of intellectual property objects. Accordingly, it could lead to an increase of the activity of addressing the issues of private international law in disputes arising from these relations. However, according to Christie's study it is not so. If the indicators of the settlement of Internet intellectual property disputes are low even for the developed countries, then Belarus should increase attention to the legal support of these relations. Otherwise they can be latent and non-existent in a multi-jurisdictional context that is international in nature. Special legal regulation can be seemed as one of the necessary supportive measures, since in this way online relations can be extracted from the gray zone of uncertainty of adaptation and unpredictability of the results of legal regulation on the ground of general rules.

Belarus has an advanced information and communications technology (ICT) industry sector. According to the International Telecommunication Union, the ICT Development Index of the country is ranked 32 out of 176 countries (ICT Development Index. 2017. Accessed April 14, 2018. https://www.itu.int/net4/ITU-D/idi/2017/index.html). In recent decades the creation and export of ICT products in Belarus has received sufficient government support and is one of the top-priority economic sectors. In 2005 the Hi-Tech Park (HTP) was established with the main goal of supporting the software industry (HTP Belarus. 2018. General information about HTP. Accessed 15 April, 2018. http://www.park. by/topic-about_htp). HTP provides a special legal regime for international IT business cooperation. 192 companies are registered as HTP residents. More than a half of them are foreign companies and joint ventures. Consequently, even one particular example makes it clear that there are appropriate conditions in Belarus for the development of relations 
that are potentially challenging specific private international law mechanisms for ubiquitous infringements.

The cases of infringements on intellectual property rights as a result of the unauthorised use of intellectual property objects on the Internet are not rare in Belarusian judicial practice. However, they are considered without specific considerations for the online infringement that can characterise it as ubiquitous and trigger the application of private international law norms and mechanisms. For example, it concerns targeting and accessibility. When an intellectual property object (copyrighted work, registered trademark, etc.) is used on a website created outside the jurisdiction of a court or operates in such a way as to attract foreign users, a plaintiff or a court may consider that there are signs of an ubiquitous infringement and raise private international law questions. These questions have not been investigated in Belarusian judicial practice significantly enough. However, current case law shows that courts and parties are eager to deal with the technical aspects of the Internet, particularly the evaluation of the unlawful use of intellectual property objects on the Internet and the assessment of evidence confirming an infringement (see f. e.: Supreme Court of the Republic of Belarus: decision of 08.11.2018, case no. 12-01/932018. Accessed 14 April, 2018. http://court.gov.by/ru/justice_rb/praktice/intell/foto/ d877f7c816e64b7b.html). It indicates the acquisition by Belarusian courts of the skills necessary to deal with Internet infringements, since, previously, there were cases when courts appointed expertise to clarify the technical aspects of online activity and the use of intellectual property objects on websites, platforms and other parts of the virtual space.

At the same time, it is noteworthy that a specialized arbitration has been created in Belarus to settle information technology and intellectual property disputes. The Arbitration court for information technology and intellectual property disputes (IT\&IP Arbitration Court) is a division of the Association of Information Technology (AKIT). It was registered according to the decision by the Justice Department of the Minsk City Executive Committee in 2015 and aims to settle the disputes between legal entities and individuals in the ICT sphere, including disputes on recognition and challenges to authorship; recovery of compensation under the license, sublicense, other agreements; compensation, and damages, caused by the illegal use of intellectual property; suppression of intellectual property rights infringements, etc. (IT\&IP Arbitration Court. 2015. Accessed 10 April, 2018. http://www.akit.by/index.php?option=com_content\&view=article\&id=16\&Item $\mathrm{id}=10$ ).

There are factual and institutional grounds for the rapid development of Internet relations on intellectual property in Belarus. Consequently, the probability of occurrence of disputes based on ubiquitous infringements is high. Necessary means exist for the resolution of such disputes and they provide two main options: to sue in national courts and rely on private international law rules and mechanisms of "lex fori"; or to use alternative dispute resolution and select the applicable law.

From the practical point of view, legal instruments in both options are quite complex and require a certain strategy to meet the risks associated with the recognition and enforcement of foreign judgments and arbitral awards. From the point of legal technique, Belarusian private international law demands modifications in order to make wordings of conflict of laws norms more transparent and functional. The main problem is that these norms can be interpreted in different ways and do not regulate many aspects, for example arbitrability and exclusive jurisdiction for intellectual property disputes; restrictions on 
party autonomy to choose applicable intellectual property laws, etc. The problem of modernizing Belarusian legislation is rather complex. To emphasize the specifics of the flexible understanding of the territoriality of intellectual property we dwell on the necessary changes of the conflict of laws rules.

2.3. Internet self-regulation ability. Actually, the second of the two options mentioned above is based on self-regulation mechanisms. To a certain extent, the Internet can be viewed as a space where disputes can be resolved without the use of national legal systems, including state legislation, courts and government bodies (for example, patent offices). If the results of an alternative dispute resolution, in particular, an amicable settlement or an arbitral award can be enforced without the use of state mechanisms, then the problem of the territoriality can be avoided and not taken into account by parties of the dispute and alternative dispute resolution bodies. The ability of self-regulation on the Internet is based on its technical infrastructure and can be provided by the Internet service providers and other Internet intermediaries.

The peculiarities of the Internet environment give rise to the discussion concerning the need for completely new legal mechanisms for the digital economy. In particular, the concept of digital rights is substantiated in this sense (Sitdikova and Sitdikov 2018, 80). The technological basis and professional participants of online relations determine the rationale and implementation of the concept. In the Russian doctrine there is a reasonable justification that while providing access to the Internet, providers objectively create preconditions for the violation of copyright and related rights (Terletskiy 2003).

Almost all actions on the Internet, in particular access to the Internet, placement of information in the virtual space, including content that violates intellectual property rights, are supported or accomplished by the Internet service providers. These persons usually receive allegations of infringements on intellectual property rights. Nevertheless, namely the Internet service providers play a key role in ensuring actions to remedy the situation of infringement. In particular, they can use their technical facilities to:

- warn users about illegal activity;

- eliminate unauthorised content from websites;

- transfer domain names to intellectual property rightholders, etc.

In particular, Anton G. Sergo substantiates that, despite the incompatibility of the online dispute settlement mechanism for domain names with the Russian legal system, it has clear advantages and allows, in certain cases, to combat the infringements of rights (Sergo 2011).

There is a tendency of developing the Internet service providers' activity to respect the goals of public policy, which are expressed by states or intergovernmental organisations. This activity is necessary to secure innovative solutions and best practices on the Internet. It is important to note, that in carrying out the required actions the Internet service providers bear the burden of expenses (Edwards 2011). In particular these problems are addressed during the EU copyright reform in the digital market (European Commission. 2019. "Copyright reform clears final hurdle: Commission welcomes approval of modernised rules fit for digital age": Press Release. Luxemburg. Accessed April 21, 2019. http:// europa.eu/rapid/press-release_IP-19-2151_en.htm). There are some limits of the willingness of Internet service providers to act as some kind of filters or barriers for unlawful content infringing intellectual property rights. However, the link between the "bona fide" behaviour of the Internet service providers and jurisdiction of a particular state can be 
found. The question is: the law of which state is at stake? From the point of view of material regulation, it is the law of the country where the Internet service provider has received a permit for professional activities in the corresponding capacity. Conflict of laws rules do not allow one to answer the question so easily. Some existing patterns of regulating activities of Internet service providers in different relations can illustrate the problems of conflict of laws in intellectual property relations.

Internet service providers do not transfer payments to jurisdictions where certain activities are put under control or banned, for example, Internet gambling transactions. The territoriality of intellectual property does not allow for such a simple solution. Ubiquitous infringement of intellectual property rights implies ubiquitous protection of these rights. The Internet service providers cannot check the legal status of an intellectual property object, including the following details: identity of a rightholder; fulfilment of formalities; compliance with terms of protection; exhaustion of rights; grounds of free use. Ideally, it should be done for all jurisdictions. Internet service providers cannot do it not only because of a lack of necessary skills or facilities. They do not have the authoritative powers to establish the existence of corresponding legal facts (authorship, status of a rightholder). Internet service providers make their conclusions on the basis of evidence supplied by a claimant ("Overview of WIPO Panel Views on Selected UDRP Questions. WIPO Jurisprudential Overview 3.0". 2017. 3 edn, para. 4.2. Accessed April 12, 2018. www.wipo.int/ amc/en/domains/search/overview3.0).

Thus, it is not correct to speak about the far-reaching possibilities of self-regulation. Instead, we see the formation of the practice of active participation of Internet service providers in various procedures in order to prevent or eliminate ubiquitous infringements on intellectual property rights. This practice is supported by the legislation of some countries, which allow or prescribe blocking Internet resources on the basis of a presumption of infringement. In the Republic of Belarus, such legislation has not been adopted. Internet service providers play an important role in resolving the problem of infringements by providing their premises for alternative dispute resolution. This practice is impressive with regard to the illegal use of intellectual property objects in domain names. The features of self-regulation can be seen in the technical actions fulfilled by an Internet service provider as prescribed in decisions delivered by arbitral tribunals (panels according to UDRP) (Uniform Domain Name Dispute Resolution Policy 1999. Accessed November 12, 2018. https://www.icann.org/resources/pages/policy-2012-02-25-en). For example, the transfer of a domain name registration to another person can serve as an example of the technical actions of an Internet service provider substituting recourse to other remedies through national legal systems. The use of these specific forms of arbitration for the settlement of Internet disputes has not received significant development in Belarus.

2.4. Specifics of conflict of laws on Internet relations. It is possible to distinguish two main institutions that decide the question of applicable law: national courts and the international arbitral tribunal. They deal with this issue in different ways, and the rules of conflict of laws that they use vary in content. National courts are obliged to follow their domestic conflict of laws. International arbitral tribunals are free to choose any rules, including rules chosen by parties. Moreover, international arbitral tribunals can determine applicable law not only on conflict of laws rules that are in force in a particular country, but also on any set of rules. It also implies application of conflict of laws rules developed by international organisations or those that have appeared due to the practice of settlement of 
disputes in a certain area of international relations. The freedom of international arbitral tribunals in determining conflict of laws is provided by Article 36 of the Law of the Republic of Belarus "On International Arbitration Court (Tribunal)" (Law of the Republic of Belarus no. 279-Z of July 9, 1999 (Amended as of July 1, 2014) "On International Arbitration Court (Tribunal)". Accessed April 13, 2018. http://law.by/document/?guid=3871\&p0 $=\mathrm{H} 19900279 \mathrm{e})$. An international arbitration tribunal can omit this issue completely. Such an approach is typical for the process of considering cases regarding online intellectual property relations with a foreign element. For example, it has become common practice in disputes on intellectual property infringements in domain names and complaints procedures on the online illegal use of intellectual property that rightholders justify intellectual property rights on legal norms at their discretion, while the conflict of laws question is not raised. To a certain extent, such an approach can be compared with the practice of applying the conflict of laws rule called "lex benegnitatis". This can be understood as the law that is most favourable for the status of a weak person in a relation. In regards to intellectual property, this rule can work in the following way - the claimant refers to the law of the country, for which it has a valid trademark registration, while the infringement is ubiquitous and the expected decision calls for the measures (such as domain name transfer) to be taken for several jurisdictions. From the point of view of the litigation (in a state court), such an approach is incorrect. However, in a virtual environment where there are grounds for self-regulation, both according to usages (rules of dealing) and dispute resolution mechanisms, it seems to be acceptable.

Panels for domain names disputes and Internet service providers are not inclined to go into depth and to spend a lot of time investigating sophisticated legal issues, but it does not mean that they act in a due course of law. By acting mechanically online, intermediaries can impair the legal interest of other stakeholders, for example real rightholders, users having rights of free access, etc. and their conclusions and acts can be affronted in courts. In fact, it is a duty of courts to deal with the conflict of laws question. Thus, it is necessary to raise conflict of laws questions in the online intellectual property relations at least for these reasons.

Finding specific conflict of laws rules for online intellectual property relations on the Internet should be determined by specific considerations about the possibility of self-regulation of the Internet environment. Otherwise, it would not correspond to the functioning of the Internet and would cause unnecessary interference to the free flow of information in the globalized world of the information society. Methodologically, the course of reasoning should go from the general to the particular in three steps. Firstly, it is possible to formulate an optimal general conflict of laws rules for intellectual property relations that take into account the importance of the problem of territoriality for national interests. The general rule can remain to be "lex loci protectionis" with its application depending on the concept of territoriality adopted in the country of a court. Hence, national courts can allow the application of foreign intellectual property law to a greater or lesser extent. Secondly, exceptions to the general rule should take into account the need to maintain legitimacy of relations that have arisen under the laws of foreign countries. It is quite a flexible scheme appropriate for offline situations, but it is not sufficient to meet the peculiarities of online intellectual property relations. Ubiquity of these relations requires a completely different approach. Thirdly, the principle of territoriality must be abandoned to a much greater degree with respect to online intellectual property relations because 
they are initially multi-jurisdictional. Here, it is not about relations involving two or more jurisdictions. In the overwhelming majority of cases, Internet relations are aimed at global coverage. Internet sites, platforms, and intermediaries are inclined to self-regulation and clarification of their mode of operation and providing services because national laws can be adjudicated to quite a different extent considering specifics of the Internet. In order to create a unified legal regime, these professional actors and participants of the global virtual world rely on some uniform standards of conduct. This phenomenon receives different names ("lex electronic", "lex informatica", "Netiquette") and can be compared with "lex mercatoria" in international trade. In terms of content, the rules of self-regulation usually have an additional or explanatory character, such as a three stage test of the UDRP in domain names disputes. Nevertheless, in some cases they may differ significantly from the mandatory prescriptions of national law, such as open licenses and other ways to provide the legal use of intellectual property rights on the Internet. Taking into account the rules that express standards of conduct in the Internet environment, they are most important for assessment of proper behaviour in online infringements of intellectual property rights.

\subsection{New conflict of laws within the principle of territoriality and respecting digital} rights. At present, legislation of the Republic of Belarus is being significantly modernised in order to introduce detailed regulation of private law relations in the field of ICT. For example, it concerns the adoption of legal acts to legitimize new phenomena in the development of ICT (tokens, crypto-currency, mining, blockchain) for commercial purposes (Decree of the President of the Republic of Belarus no. 8 of 21 December, 2017 "On the Development of the Digital Economy". Accessed April 14, 2018. http://law.by/document/ ?guid=3871\&p0=Pd1700008e). However, new models of intellectual property regulation, especially regarding online intellectual property infringements, are not reflected in Belarusian law. Thus, first of all it is necessary to adopt acts of legislation containing material norms. At least they should concern the following: legal status of Internet service providers and other Internet intermediaries as participants of intellectual property relations, including the question of their liability and responsible behaviour; blocking to prevent the illegal use of intellectual property objects on the Internet.

Respectively, conflict of laws rules should be adjusted to regulate online intellectual property relations and should be made more open to the specifics of the Internet. It could be done by the following scheme of modernizing the set of conflict of laws rules on intellectual property:

- modifying the wording of the general rule in Article 1132 of the Civil Code of the Republic of Belarus, "the law of the country where protection is sought" to "the law of the Republic of Belarus";

- adding the criterion of the close connection to the general rule in order to establish an exception that allows for the recognition of legal consequences of intellectual property relations, despite the principle of territoriality. The corresponding rule should state "Herewith the court can apply legal norms of another country that have the close connection with the relationship in question" (it is implied a connection between legal norms and relations, for example when the relation has arisen due to the effect of these norms);

- creating a new article with the following rules: 
"1. The infringement of intellectual property rights on information and telecommunication networks, including the Internet, is determined by the law of the country with which the infringement is most closely connected.

2. In determining which state has the greatest connection with the infringement, the court should take into account all relevant factors, in particular the following:

3. In app the infringer's place of residence;

- the infringer's main place of activity;

- the place where substantial activities in furtherance of the infringement in its entirety have been carried out;

- the place where the harm caused by the infringement is substantial in relation to the infringement in its entirety.

lying the law determined in accordance with paragraph 1 and paragraph 2 of this article, the court must take into account rules and standards of conduct commonly used on the information and telecommunication network which is directly related to the infringement".

It is expedient to maintain the ratio of lex loci protectionis and criterion of the closest connection, which is traditionally substantiated in the doctrine (Suspitsyna 2013). But, it is necessary to identify general and special norms clearly determining types of relations, exemptions and methods of reference to an applicable law, as well as the degree of court discretion. The conflict of laws rule "lex loci protectionis" is imprecise and does not allow to connect two places, which are of crucial importance for intellectual property rights in private international law, i. e. the place of litigation and the place of afforded and recognised protection. We consider the multivariate interpretation of the direction of reference, which is thoroughly investigated in the works of scientists (see f. e.: Lutkova 2016; Krupko 2014), the main argument in favour of rejecting it. "Lex loci protectionis" must be abandoned as it does not provide the court a direct indication, but implies a long chain of conclusions. Moreover, this rule competes with some material norms regulating intellectual property relations with a foreign element, including those that take into account a foreign intellectual property law. Thus, it is not for conflict of laws to decide, whether an intellectual property object is protected or not. This question is considered on material norms of imperative nature. While searching the law of the country where or for which protection is sought, the court will constantly be confronted with the need to follow the principle "lex specialis derogat lex generalis", which was remarkably characterized by V. Kudashkin for material and conflict of laws norms (Kudashkin 2004).

The rule of close connection in the recommended new article works in a different way. It aims to find the connection of the disputed intellectual property relationship with the particular norms and the country, which determines the essence and existence of the relationship. It is necessary to overcome shortages of the principle of territoriality. That is why it works as an exemption. Infringements on the information and telecommunication networks are initially and immanently multi-jurisdictional in its essence. Thus, the recourse to the law of a particular country, firstly, must not be limited by "lex fori" and, secondly, allow the application of self-regulatory rules. The third paragraph of the proposed new article reflects tendencies in private international law to broaden the cumulative and alternative techniques of conflict of laws linkage. As it is mentioned by Wilhelm Wengler, such an approach in reality can favour one party over the other (Wegler 1963, 832). But, 
we proceed from the assumption that cumulation is permissible in favour of relations in general, taking into account the circumstances of its occurrence.

In the formulated scheme, it provides a combination of different types of sources of legal regulation (national law and usages). Cumulation with reference to the rules of the online environment is especially important. These rules appear due to the self-regulation. They clarify issues that are absent in national laws or perhaps shall not be regulated by national laws at all due to overly complicated and specific technical matters. For example, the rules and standards of conduct commonly used on the information and telecommunication network may be taken into account in relation to quotations, citation, indication of an author, and other issues of "good faith" with regard to digital rights, for example use of a work in a certain electronic form.

\section{Conclusions}

Conflict of laws regulation in digital economy must provide an opportunity to overcome the contradiction between the essential unity of the object of intellectual property and the multiplicity of forms of its legal protection in several jurisdictions. In the circumstances of a particular case, the application of foreign intellectual property laws may prove decisive for the legal fate of the relationship. The formulation of various rules for finding an applicable law for intellectual property relations should be based on a specific goal. Belarus has specific interests in access to the knowledge for the purpose of innovation, scientific and technological development and material norms on intellectual property express the goals of public policy. In such circumstances, the principle of territoriality is of paramount importance both for material and conflict of laws regulation. The economic rationale for "lex fori" (in a precise wording "the law of the Republic of Belarus") is that intellectual property is the monopoly permissible under the prescriptions of national legislation, which limits free access to modern achievements in science, culture, art, etc. Each state correlates the level of its economic development with the rules of protection of intellectual property rights concerning types of protectable intellectual property objects, term of protection, rules on enforcement, etc. At the same time, the territorial character of the intellectual property rights acquired abroad does not mean that within Belarusian jurisdiction the signs of the existence of these rights should not be taken into account. It especially concerns online intellectual property relations immanently connected with several jurisdictions and relying on the self-regulation capacity of the digital environment.

\section{References}

Baranovskiy, Petr D. 2005. International legal problems of protection of intellectual property on the Internet). Moscow, Moskovskaia gosudarstvennaia iuridicheskaia akademiia Publ. (In Russian)

Bliznets, Ivan A. ed. 2018. Intellectual Property Law. International legal regulation. Moscow, Iurait Publ. (In Russian)

Christie, Andrew F. 2017. "Private international law principles for ubiquitous intellectual property infringement - a solution in search of a problem?" Journal of Private International Law 13(1): 152183. doi:10.1080/17441048.2017.1304047.

Christie, Andrew F. 2015. Private International Law Issues in Online Intellectual Property Infringement Disputes with Cross-Border Elements: An Analysis of National Approaches. Geneva, WIPO. Accessed April 12, 2018. www.wipo.int/edocs/pubdocs/en/wipo_rep_rfip_2015_1.pdf. 
Dinwoodie, Graeme B. 2009. "Developing a Private International Intellectual Property Law: The Demise of Territoriality?” William \& Mary Law Review 51(2): 711-800. Accessed April 12, 2018. http//www.ssrn. com/link/oxford-legal-studies.html.

Dubay, Carolyn. A. 2012. "Private International Law Discourse: The Legacy of Friedrich Carl von Savigny". International Judicial Monitor. Accessed April 12, 2018. www.judicialmonitor.org/archive_spring2012/ privateinternationallawdiscourse.html.

Edwards, Lilian. 2011. “The Role of Internet Intermediaries in Advancing Public Policy Objectives Forging Partnerships for Advancing Policy Objectives for the Internet Economy, Part II”. SSRN. Accessed April 15, 2018. http://dx.doi.org/10.2139/ssrn.1875708.

Krupko, Svetlana. 2014. "Conflict of laws aspects of intellectual property regulation”. Khoziaistvo i pravo 11: Prilozhenie. (In Russian)

Kudashkin, Vladimir V. 2004. Actual issues of private international law. Moscow, Volters Kluver Publ. (In Russian)

Lundstedt, Lydia. 2016. Territoriality in intellectual property law: A comparative study of the interpretation and operation of the territoriality principle in the resolution of transborder intellectual property infringement disputes with respect to international civil jurisdiction, applicable law and the territorial scope of application of substantive intellectual property law in the European Union and United States. Stockholm, Stockholm University.

Lutkova, Oksana V. 2016. "Principles of legal regulation of transboundary copyright relations". Vestnik Universiteta imeni O. E. Kutafina 12 (28): 63-92. (In Russian)

Petz, Thomas. 2012. "Ubiquitous Infringement". Intellectual property and private international law: Comparative perspectives, 217-346. Oxford, Hart.

Ruse-Khan, Henning G. 2017. The protection of intellectual property in international law. Oxford, Oxford University Press.

Sergo, Anton G. 2011. The legal regime of domain names and its development in civil law. Moscow, Rossiiskii gosudarstvennyi institut intellektual'noi sobstvennosti Publ. (In Russian)

Shugurova, Irina V. 2010. “The territorial principle of intellectual property rights: the main trends". Sovremennoe pravo 10: 76-81. (In Russian)

Sitdikova, Roza I., Ruslan B. Sitdikov. 2018. "Digital rights as a new kind of property rights". Imushchestvennye otnosheniia $v$ RF 9(204): 75-80. (In Russian)

Suspitsyna, Mariia V. 2013. Conflict of laws regulation of intellectual property relations. Moscow, Moskovskaia gosudarstvennaia iuridicheskaia akademiia Publ. (In Russian)

Terletskiy, Vasilii V. 2003. Protection of copyright and related rights when using protected objects in digital networks and multimedia products. Moscow, Rossiiskii gosudarstvennyi institut intellektual'noi sobstvennosti Publ. (In Russian)

Wegler, Wilhelm. 1963. "The significance of the principle of equality in the conflict of laws". Law and Contemporary Problems 28(4): 822-859.

Received: April 25, 2019

Accepted: February 19, 2020

Author's information:

Elena Leanovich — PhD in Law, Associate Professor; leanovich@bsu.by 